\title{
EXTRACTION OF SOME CALCIUM AND MAGNESIUM SALTS FROM WASTE WATER OF REGENERATION PROCESS IN DEMINERALIZATION PLANT.
}

\author{
E.M. Khalil ${ }^{1}$, A.B.Farag ${ }^{1}$, Kh. El-Nagar ${ }^{2}$, A.I. Shehata ${ }^{3}$, R.A.Ellaithy ${ }^{4}$ \\ Departments of ${ }^{1)}$ Chemistry, Faculty of Science, Helwan University. ${ }^{2}$ Chemical Metrology Division, National \\ Institute for standard. ${ }^{3)}$ Central Chemical lab. Egyptian Electricity Holding Company. ${ }^{4)}$ El tebbin Power Station, \\ Cairo Electricity Production Company.
}

\begin{abstract}
The produced water from cation exchanger regeneration processes has been enriched by calcium and magnesium salts (very hard water). In this research, extraction of calcium and magnesium salts in the form of magnesium and calcium hydroxide (Lime) will carry out during adjusting $p H$ of cation regeneration wastewater by adding anion regeneration wastewater. The extracted salts were dried and characterized by using chemical analysis, IR spectrum and X-ray analysis. Results indicated that an increase in the addition of anionic wastewater to cationic wastewater up to $60 \%$ caused a decrease in total hardness, magnesium hardness and calcium hardness concentrations in cationic wastewater up to $80 \%$. However, the maximum percentage recovery of calcium salts obtained at $\mathrm{pH}$ values between 10-11, while those of magnesium salts were between11-12.

Keywords: Waste water, Hardness, Cation exchanger, Calcium, Magnesium, Regeneration.
\end{abstract}

\section{INTRODUCTION}

Demineralization water treatment or de ionization water treatment process is the removal of essentially all inorganic salts by ion exchange. In this water treatment process, strong acid cation resin in the hydrogen form converts dissolved salts into their corresponding acids, and strong base anion resin in the hydroxide form removes these acids ${ }^{[1]}$. Demineralization water treatment plant produces water similar in quality to distillation at a lower cost for most fresh waters. A demineralizer water treatment system consists of one or more ion exchange resin columns, which include a strong acid cation unit and a strong base anion unit ${ }^{[2]}$. The wastewater produced from regeneration process has a higher amount of salts especially calcium and magnesium salts ${ }^{[3]}$. This wastewater is like brine solution (saline solution). Previous studies have shown that salts in brine can be recovered and purified as commercial products. Salts have been recovered from salty lakes ${ }^{[4]}$, sea water ${ }^{[5]}$, textile effluent ${ }^{[6]}$, concentrate at a sugar decolorization plant ${ }^{[7]}$, and industrial effluent ${ }^{[8,9]}$.

Due to the lack of adequate methods for the disposal of waste brine produced during demineralization processes, environmental pollution will created. The most common methods to treat concentrates include: (1) disposal to evaporation ponds ${ }^{[10-12]}$, (2) discharge in deep disused gold mines or wells ${ }^{[13]}$ and (3) coastal discharge $\mathrm{e}^{[14 \text {, }}$
${ }^{16]}$. However, Buckley, et al. (1987) ${ }^{[17]}$ suggested the following additional methods for treatment of waste brine:

(1) Engineering out the source of brine: reducing the dissolved solids in the brine by implementing chemical or engineering changes in the production process.

(2) Converting brine into useful chemicals: recycling, or recovering chemicals or salts from the waste brine.

(3) Deactivation or conversion of brine to an inert substance: deactivating waste brine by transforming it into unreactive or insoluble compounds.

The objective of this work is to find a new technique to extract some salts from cation exchange waste water by the addition of anion exchange waste water at proper conditions.

\section{METHODS AND MATERIALS}

\section{Source of Water Works Samples:}

2-1-1.Very hard wastewater was obtained from Cation Regeneration Waste Water (CRWW) of demineralization plant with an ingredients present in table (1).

2-1-2.Alkaline wastewater was obtained from Anion Regeneration Waste Water (ARWW) of the same demineralization plant with an ingredients present in table (1). 


\section{2-2. Precipitation of Calcium and Magne-} sium salts:

A calculated amount of (ARWW) was added to one liter of (CRWW). The $\mathrm{pH}$ of (CRWW) was increased by these additions until reached to 10.5 at this point calcium carbonate was precipitated and isolated by filtration through filter paper. The remained filtrate will go through furthermore addition of (ARWW). This addition leads to increase $\mathrm{pH}$ to 11.5 at this point magnesium hydroxide precipitated and isolated by filtration. Both of two precipitates were heated at $650 \mathrm{C}^{0}$ to produce calcium and magnesium oxide.

\section{2-3. Chemicals Analysis and Tests:}

\section{2-3-1. Chemicals:}

- Calcium and magnesium oxide of pure grade used as standard materials.

- All chemicals that used in the analysis in this work were of laboratory chemical grade.

\section{2-3-2. Analysis:}

The following series of water examination and chemical analysis were carried out accord- ing to the standard method of ASTM Book of Standards (ASTM, 2001).

- Total hardness, Calcium and magnesium hardness and alkalinity of water determined in $(\mathrm{mg} / \mathrm{L})$ as $\mathrm{CaCO} 3$ by titration with EDTA according to ASTM Book of Standards (ASTM, 2001).

- $\mathrm{pH}$ of waste water was measured by pH meter model 810 Fisher scientific .

- The removal efficiency (\% Recovery) was calculated from the following formula:

$\%$ Recovery $=C_{0_{-}} C / C_{0} \times 100$

Where, $\mathrm{C}_{0}$ and $\mathrm{C}=$ initial and final concentration of the elements.

- X-ray analysis of dry salts: The dry salts of calcium and magnesium were analyzed by using; Energy Dispersive X-ray System., ISIS Link Instrument P/C. Oxford Co.

- IR spectra were performed by using FTIRATR spectra of the above mentioned samples were recorded by means of Nicolet 380 Spectrometer. The FTIR absorbance frequencies for the samples were recorded with an average of 128 scans using a resolution of $4 \mathrm{~cm}^{-1}$.

Table ( 1 ) Chemical analysis of Cation and Anion Waste Water .

\begin{tabular}{|c|c|c|c|}
\hline \multicolumn{2}{|l|}{ Cation waste water } & \multicolumn{2}{|l|}{ Anion waste water } \\
\hline Analysis & value & Analysis & value \\
\hline $\begin{array}{l}\mathrm{Ph} \\
\text { Total Hardness } \mathrm{mg} / \mathrm{L}\left(\text { as } \mathrm{CaCO}_{3}\right) \\
\text { Calcium Hardness } \mathrm{mg} / \mathrm{L}\left(\text { as } \mathrm{CaCO}_{3}\right) \\
\text { Magnesium Hardness } \mathrm{mg} / \mathrm{L}\left(\text { as } \mathrm{CaCO}_{3}\right) \\
\text { Sodium } \mathrm{mg} / \mathrm{L} \text { as } \mathrm{Na} \\
\text { Iron } \mathrm{mg} / \mathrm{L} \text { as Fe }\end{array}$ & $\begin{array}{l}6.61 \\
3000 \\
1750 \\
1250 \\
870 \\
2.9\end{array}$ & $\begin{array}{l}\mathrm{pH} \\
\text { Total alkalinity } \mathrm{mg} / \mathrm{L}\left(\text { as } \mathrm{CaCO}_{3}\right) \\
\text { Sodium } \mathrm{mg} / \mathrm{L} \text { as } \mathrm{Na} \\
\text { Sulphate } \mathrm{mg} / \mathrm{L} \text { as } \mathrm{SO}_{4}^{--} \\
\text {Chloride } \mathrm{mg} / \mathrm{L} \text { as } \mathrm{Cl}^{-}\end{array}$ & $\begin{array}{l}12.75 \\
11300 \\
6875 \\
1850 \\
6300\end{array}$ \\
\hline
\end{tabular}

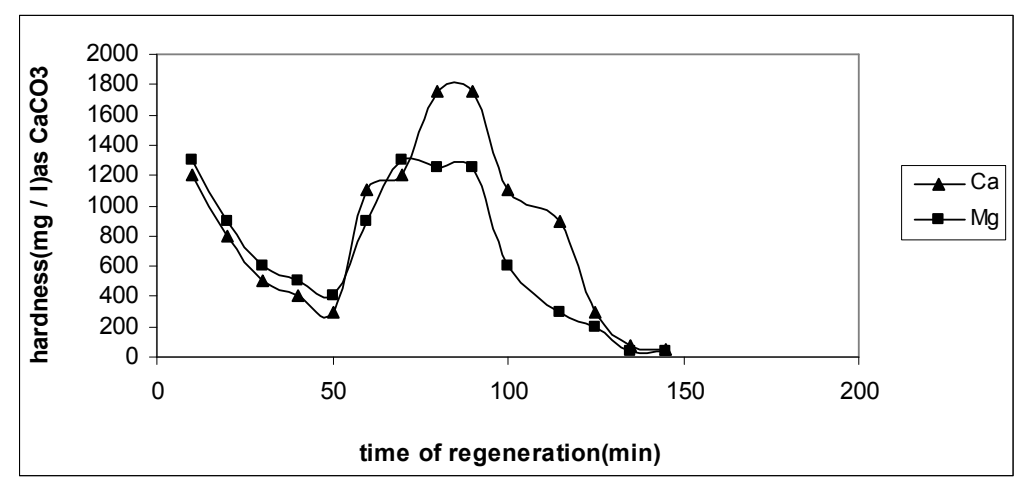

Figure (1): Variation of Calcium and Magnesium hardness during regeneration time of exhausted cation exchange. 


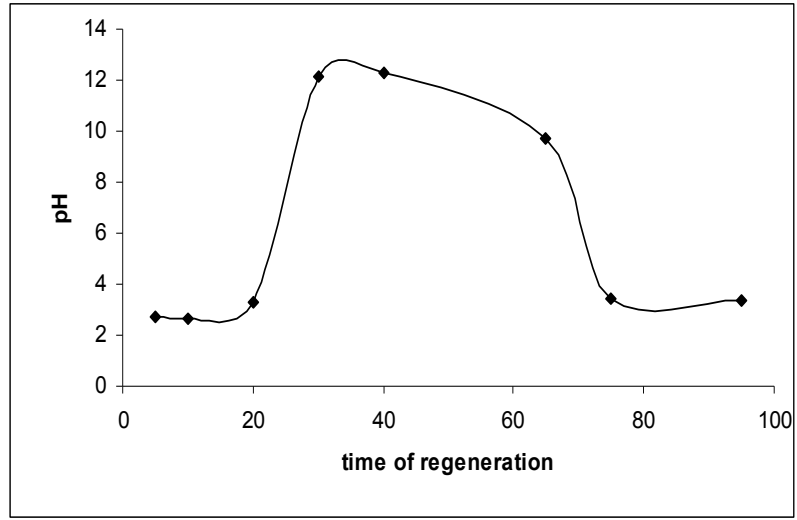

Figure ( 2 ): Variation of $\mathrm{pH}$ value during regeneration time of exhausted anion exchange.

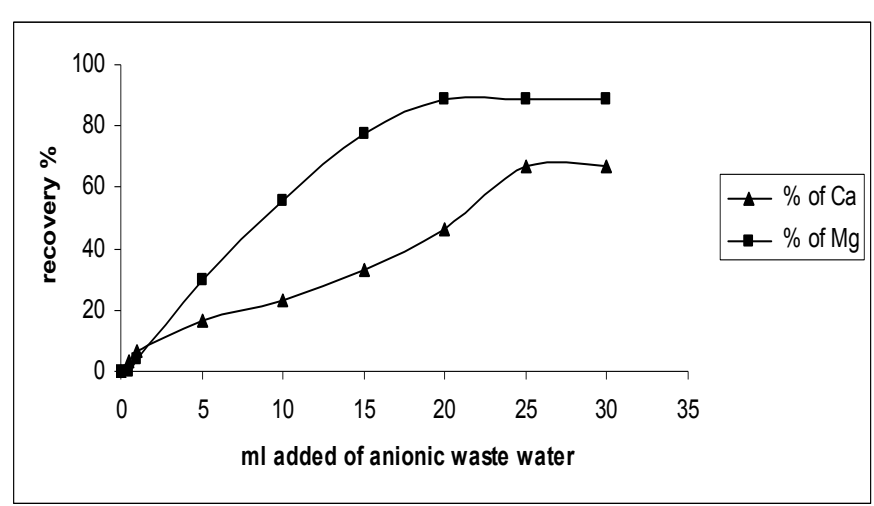

Figure (4) Effect of $\mathrm{ml}$ added of (ARWW) on \% recovery of calcium and magnesium ions.

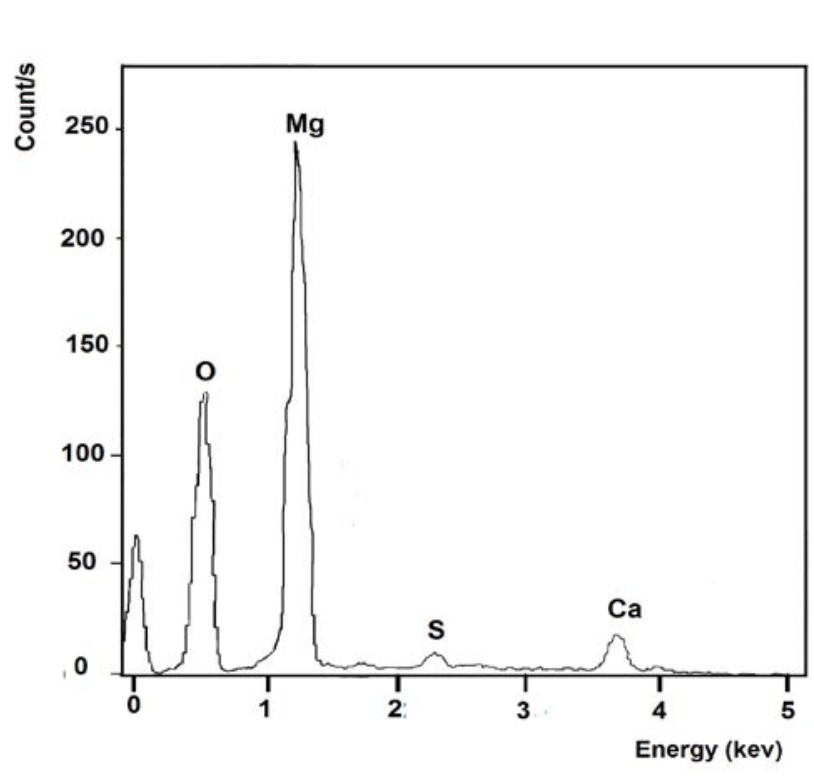

Figure (6) X-ray of extracted salt at pH 11.5.

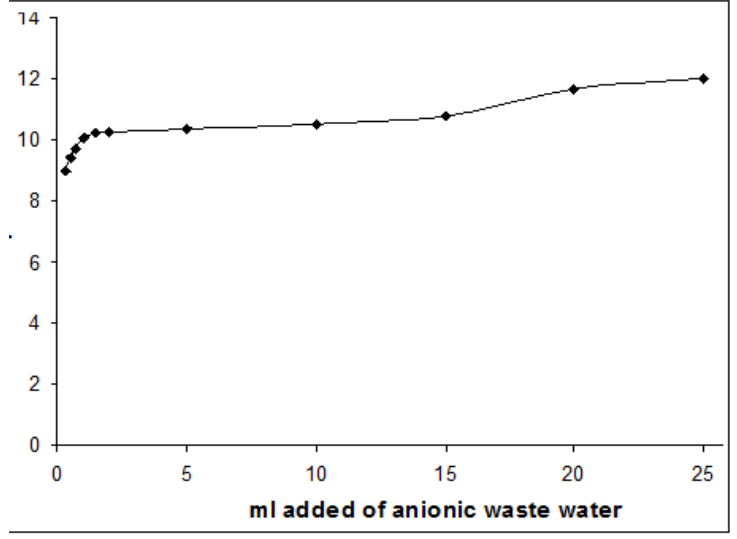

Figure (3) Effect of $\mathrm{ml}$ added of (ARWW) on the pH of (CRWW).

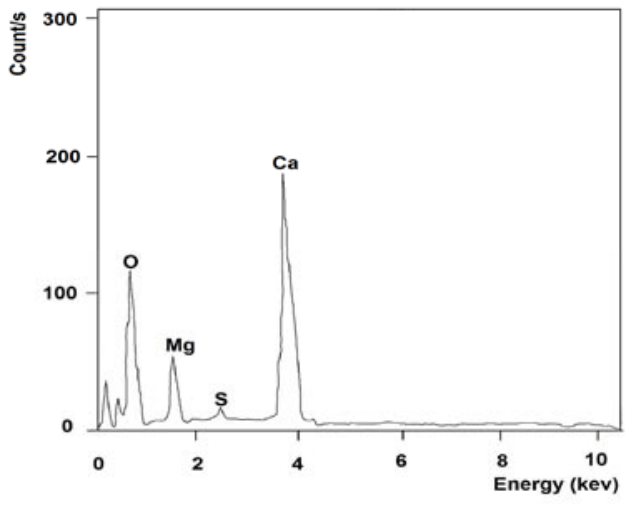

Figure (5) X-ray of extracted salt at pH 10.5.
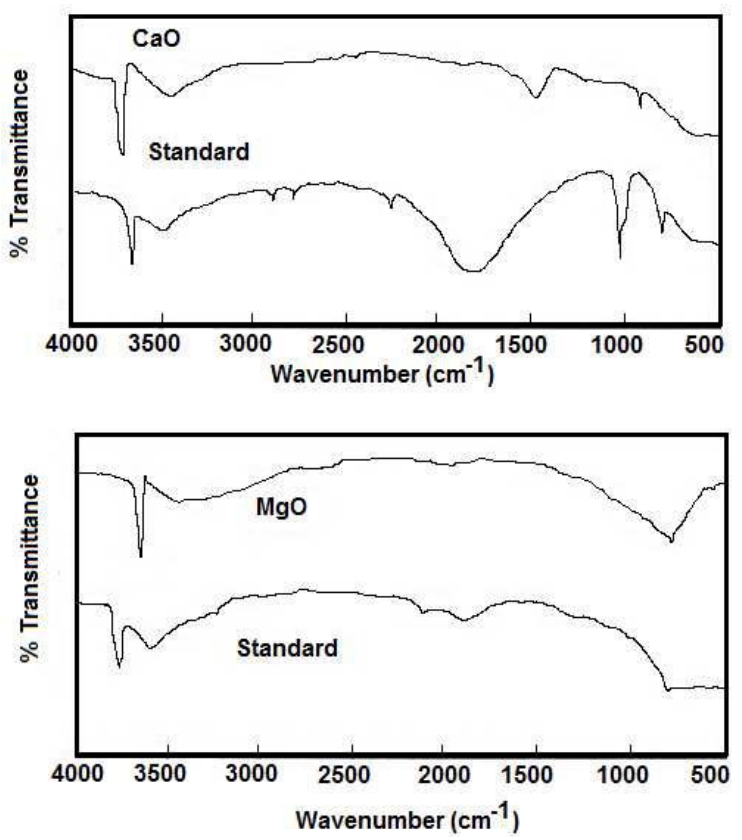

Figure (7) FTIR Spectra of recovered and standard calcium and magnesium oxide. 


\section{RESULTS AND DISCUSSION}

\section{3-1. Theory of Ion Exchange in the Demin- eralization Plants}

The process of water demineralization is operated in the demineralization plant as follow:

\section{3-1-1. Operation Process of Cation Ex- change:}

The most ingredients of working raw water are Calcium and magnesium salts present in the form of (sulphates, chlorides, carbonates and bicarbonates). When this water passed through cation exchange resin, the exchange occurs according to equation (1):

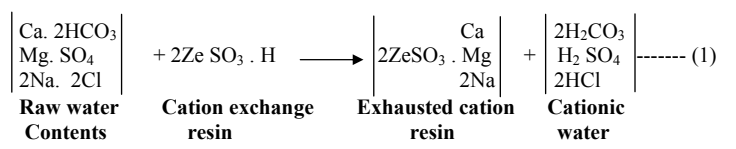

\section{3-1-2. Operation Process of Anionic Ex- change:}

The cationic water passed through anion exchange resin, the exchanges are donning to produce demineralized water according to equation (2):

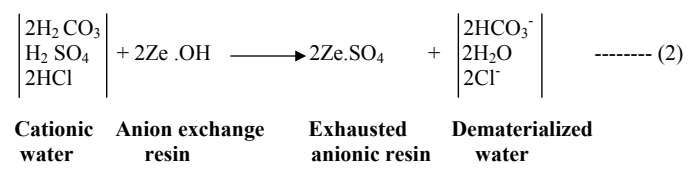

3-1-3. Regeneration Process of Cation Exchange:

After ion exchange resin exhaustion the resin will go through regeneration processes. The regeneration process occurs by using sulfuric acid according to equation (3):

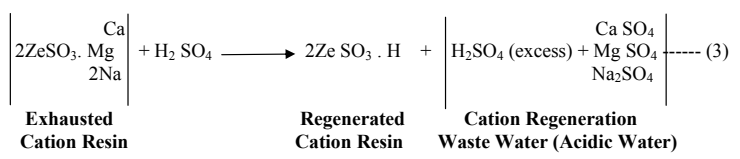

\section{3-1-4. Regeneration Process of Anion Ex- change:}

The regeneration process occurs by using sodium hydroxide according to equation (4):

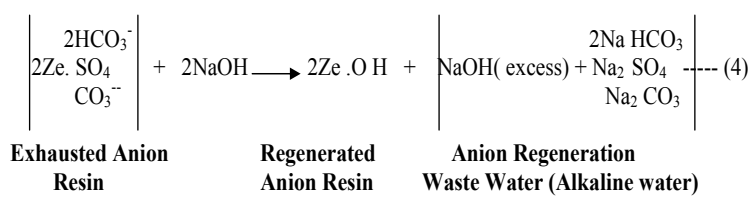

\section{3-2. Characterization of Waste Water:}

From the above mentioned processes we have two kinds of waste water; Cation Regeneration Waste Water (CRWW) collected from demineralization plant during regeneration process of cation exchange resin and Anion Regeneration waste Water (ARWW) collected from demineralization plant during regeneration process of anion exchange resin. The chemical analysis of (CRWW) revealed that it has been enriched by calcium and magnesium salts as can be seen from table (1). During the regeneration process calcium and magnesium hardness was at maximum concentration after 80 minuets from the beginning of regeneration process of cation exchange resin as can be seen from figure (1). While the maximum $\mathrm{pH}$ of (ARWW) where found after (30-40) minuets from the beginning of regeneration process of anion resin at this point the (ARWW) was enriched by mixture of sodium (Hydroxide, sulphate, carbonate and bicarbonate) as can be seen from figure (2). Table (1) show the chemical analysis of (CRWW and ARWW). The samples were withdrawal at the maximum concentration of calcium and magnesium for (CRWW), while at maximum $\mathrm{pH}$ for (ARWW).

\section{3-3.Calcium and Magnesium Recovery and Determination:}

\section{3-3-1.Hardness Removal Process:}

Water utilities struggling with source water that contains high amounts of calcium and/or magnesium often turn to lime softening to remove hardness. Raising treatment $\mathrm{pH}$ above 9.6 converts soluble calcium bicarbonate hardness to insoluble calcium carbonate. An increase in $\mathrm{pH}$ beyond 10.6 converts soluble magnesium bicarbonate to insoluble magnesium hydroxide. Aggressive magnesium removal often requires a treatment $\mathrm{pH}$ rang11-12.

During precipitation softening, calcium is removed from water in the form of $\mathrm{CaCO}_{3}$ precipitate and magnesium is removed as $\mathrm{Mg}(\mathrm{OH})_{2}$ precipitate .The $\mathrm{pH}$ plays an important role in the precipitation of these two solids. Carbonate hardness can be removed by the addition of hydroxide ions and raising the $\mathrm{pH}$ by which the 
bicarbonate ions are converted to carbonate form having a $\mathrm{pH}$ above 10 . Due to the increase in carbonate concentration, precipitates of calcium carbonate are formed. The remaining calcium, i.e. non carbonate hardness, cannot be removed by simple adjustment of $\mathrm{pH}$. Therefore, soda ash (sodium carbonate) must be externally added to precipitate this remaining calcium. Magnesium is removed due to the precipitation of magnesium hydroxide. In the lime soda ash process, lime is added to raise the $\mathrm{pH}$ while sodium carbonate is added to provide a source of carbonate ion.

\section{3-3-2.Precepetation of Calcium and Magnesiumsalts:}

The anion regeneration waste water (ARWW) which contains sodium (carbonate, bicarbonate and hydroxide) can provide an excellent condition for precipitation of calcium and magnesium salts when added to cation regeneration waste water (CRWW).

Therefore the addition of (ARWW) to (CRWW) were studied in accordance to provide maximum precipitation level expressed as percentage recovery by $\mathrm{ml}$ added. Figure (3) show the precipitation profile of calcium and magnesium salts during the addition of (ARWW) to the (CRWW) expressed as \% recovery by $\mathrm{ml}$ added. The results indicate that the maximum $\%$ recovery of calcium was found by adding $20 \mathrm{ml}$, while for magnesium by adding $25 \mathrm{ml}$ of (ARWW) to $100 \mathrm{ml}$ of (CRWW). Also the results indicate that the $(\mathrm{pH})$ increase with increasing $(\mathrm{ml})$ added of (ARWW) as can be seen from figure (4). Furthermore the increasing of $(\mathrm{pH})$ leads to increase the precipitation level of calcium and magnesium salts.

Figure (4) show that the maximum \% recovery of calcium salts obtained at $(\mathrm{pH})$ value between10-11, while magnesium salts was between11-12.Neveretheless the percentage recovery reached to $66.66 \%$ and $88.88 \%$ for calcium and magnesium salts respectively as can be seen from figure (4).

\section{3-3-3. Nature of the Extracted Salts:}

The extracted calcium and magnesium salts were introduced to investigation as follow:

3-3-3-1.X-ray analysis of extracted salts:
The extracted salts at $\mathrm{pH}$ (10.5) and (11.5) were analyzed by using; Energy Dispersive Xray System. The results are shown in figures (5, 6). It is clearly seen that for salt extracted at $\mathrm{pH}$ (10.5) the main peak in the chart was for calcium. Also for the salt extracted at $\mathrm{pH}$ (11.5) the main peak was for magnesium.

\section{3-3-3-2.IR SPECTROSCOPY:}

The nature of the produced salts was performed by IR spectra using FTIR-ATR spectra of the above mentioned samples. Figure (7) represent the IR spectra of both the standards $\mathrm{CaO}$ and $\mathrm{MgO}$ samples in comparison with extracted products from the waste water. The curves show that there is agreement between peaks of the extracted $\mathrm{CaO}$ and $\mathrm{MgO}$ with the standard samples.

\section{CONCLUSION}

Extraction of calcium and magnesium salts in the form of magnesium and calcium hydroxide (Lime) will carry out during adjusting $\mathrm{pH}$ of cation regeneration waste water by adding anion regeneration waste water. Results indicated that an increase in the addition of anionic waste water to cationic waste water up to $60 \%$ caused a decrease in total hardness, magnesium hardness and calcium hardness concentrations in cationic waste water up to $80 \%$. However, the maximum percentage recovery of calcium salts obtained at $\mathrm{pH}$ value between10-11, while magnesium salts was between11-12.

\section{Acknowledgment}

Authors are greatly thanking the management of the central laboratories of the Egyptian Electricity holding company.

\section{REFERENCES}

[1] Sanciolo, P., Ostarcevic, E., Atherton, P., Leslie, G., Fane, T., Cohen, Y., Payne, M. and Gray, S. (2010) Enhancement of reverse osmosis water recovery using interstage calcium precipitation. Membranes in Drinking and Industrial Water Treatment, IWA, 27-30 June, NTNU- Trondheim, Norway, paper 150173.

[2] Peter Sanciolo, Eddy Ostarcevic, Paul Atherton, Greg Leslie, Tony Fane, Yoram Cohen, Marrack Payne, Stephen Gray, Reverse osmosis waste brine volume reduction by accelerated seeded precipitation. AMS6/ IMSTEC10, The 6th Conference of the Aseanian Membrane Society \& 7th International Membrane Science 
and Technology Conference, Sydney, Australia, November 22-26, 2010, paper P-597.

[3] Peter Sanciolo, Eddy Ostarcevic, Paul Atherton, Greg Leslie, Tony Fane, Yoram Cohen, Marrack Payne, Stephen Gray, PILOT PLANT REMOVAL OF SCALE PRECURSOR IONS TO ENHANCE RO WATER RECOVERY, IDA World Congress - Perth Convention and Exhibition Centre (PCEC), Perth, Western Australia September 4-9, 2011.

[4] Ö. Kilic, A.M. Kilic, Recovery of salt co-products during the salt production from brine, Desalination 186 (2005) 11-19.

[5] E. Drioli, E. Curcio, A. Criscuoli, G.D. Profio, Integrated system for recovery of $\mathrm{CaCO} 3, \mathrm{NaCl}$, and $\mathrm{MgSO} 4 \cdot 7 \mathrm{H} 2 \mathrm{O}$ from nanofiltration retentate, Journal of Membraen Science 239 (2004) 27-38.

[6] L. Shu, T.D. Waite, P.J. Bliss, A. Fane, V. Jegatheesan, Nanofiltration for the possible reuse of water and recovery of sodium chloride salt from textile effluent, Desalination 172 (2005) 235-243.

[7] S. Wadley, C.J. Brouckaert, L.A.D. Baddock, C.A. Buckley, Modelling of nanofiltration applied to the recovery of salt from waste brine at a sugar decolourisation plant, Journal of Membrane Science 102 (1995) $163-175$.

[8] G. Li, F. Zhang, G. Zhang, J. Han, Recovery of Na2SO4 from remediation of wastewater and reuse from preparation of sodium 4-nitrotoluene-2-sulfonate (NTSNa), Desalination 194 (2006) 176-181.

[9] C. Himawan, H.J.M. Kramer, G.J. Witkamp, Study on the recovery of purified $\mathrm{MgSO} 4 \cdot 7 \mathrm{H} 2 \mathrm{O}$ crystals from industrial solution by eutectic freezing, Separation and Purification Technology 50 (2006) 240-248.

[10] Jenkins, B. M., P. Thy, P.Y. Liu, C.E. Lesher, A. Beland, and V. Cervinka, 1998. Final report — Preliminary investigation into the vitrification of salts from evaporated drain water. University of California.

[11] M. Ahmed, W.H. Shayya, D. Hoey, A. Mahendran, R. Morris, J. Al-Handaly, Use of evaporation ponds for brine disposal in desalination plants, Desalination 130 (2) (2000) 155-168.

[12] M. Ahmed, W.H. Shayya, D. Hoey, J. Al-Handaly, Brine disposal from reverse osmosis desalination plants in Oman and the United Arab Emirates, Desalination 133 (2) (2001) 135-147.

[13] A.M.O.Mohamed,M.Maraqa, J.A.Handhaly, Impact of land disposal of reject brine from desalination plants on soil and groundwater, Desalination 182 (1-3) (2005) 411-433.

[14] J.L. Hunt, K. Frazier, B.P. Pendergraft, M.Y. Soliman, Evaluation and completion procedure for produced brine and waste water disposal wells, Journal of Petroleum Science and Engineering 11 (1) (1994) 51-60.

[15] J.V. Del Bene, G. Jirka, J. Largier, Ocean brine disposal, Desalination 97 (1-3) (1994) 365-372.

[16] D. Orhon, Scientific basis for wastewater treatment and disposal in Istanbul, Water Science and Technology 32 (2) (1995) 199-208.

[17] C.A. Buckley, A.E. Simpson, C.A. Kerr, C.F. Schutte, The treatment and disposal of waste brine solutions, Desalination 67 (1987) 431-438. 